\title{
A bírósági végrehajtás és a sérelemdíj
}

\section{Judicial Enforcement and Compensation for Emotional Distress}

\section{Összefoglalás}

A sérelemdíj bevezetése a magyar jogrendszerbe bizonyos tekintetben új alapot jelent a személyiségi jogok tekintetében. A bírósági végrehajtás jogintézménye az állami, elsôsorban vagyoni kényszer alkalmazása okán ütközőpontot képezhet a sérelemdíjjal mint polgári jogi szankcióval. Mivel az egységes és következetes bírói gyakorlat még nem alakult ki, ezért jelen írás a sérelemdíj és a bírósági végrehajtás összefüggéseit vizsgálja.

Journal of Economic Literature (JEL) kódok: K10, K15, K36, K38, K42

Kulcsszavak: polgári jog, sérelemdíj, bírósági végrehajtás

\section{Summary}

In some respects, the introduction of compensation for damages for emotional distress (or other non-material grievances) places personal rights on a new footing. The system of judicial enforcement, mostly because of its reliance on government force, primarily force related to assets and property, may come into conflict with damages for emotional distress (or other non-material grievances) as a civil rights penalty. Since a unified and consistent court practice is not yet in place, this study examines the correlations between damages for emotional distress or other non-material grievances, and the system of judicial enforcement.

Dr. PAtaki János István, végrehajtási jogi szakjogász, ügyvéd (patakiugyvediiroda@gmail.com). 
Journal of Economic Literature (JEL) codes: K10, K15, K36, K38, K42

Keywords: civil rights, compensation for emotional distress, judicial enforcement

\section{BEVEZETÉS}

A nem vagyoni kártérítés helyett a sérelemdíj jogintézményét a 2013. évi V. törvény a Polgári törvénykönyvról (Ptk.) vezette be. ${ }^{1}$ Az új szabályozás értelmében az, aki személyiségi jogainak megsértéséből eredôen kárt szenved, és amennyiben bizonyítja a jogsértés tényét (egyéb joghátrányt nem kell bizonyítania), a jogellenesen okozott károkért való felelôsség szabályai szerint követelheti a jogsértôtốl kárának megtérítését. Két álláspont létezett/létezik arról, hogy a nem vagyoni kártérítés a felelôsségi jog egyik alakzatát képezi, vagy önálló, sui generis tényállásként a személyiségi jogok megsértésének szankciója (Osztovits, 2014:338). Az új Ptk. hatálybalépése a jog eszközével eldöntötte a két nézet közötti vitát, de újabb kérdéseket is generált. Mindenesetre a Ptk. értelmében a sérelemdíj kettôs funkciót lát el: egyrészt kompenzációs szerepet tölt be a személyiségi jogsérelem tekintetében, másrészt magánjogi büntetésnek tekinthetố a hasonló jogsértések megelôzésének céljával. ${ }^{2}$

A 2015. évi CVII. törvény (a bírósági végrehajtásról szóló 1994. évi LIII. törvény, és ezzel összefüggésben egyes törvények módosításáról) 6. §-a 2015. szeptember 30. napi határidố túzése mellett akként módosította a Vht. 236. § (2) bekezdését, hogy a végrehajtó köteles legalább harmincmillió forint értékú felelôsségbiztosítást kötni, és azt a múködése alatt fenntartani kártérítés, illetve a sérelemdíj fedezetére. A Ptk. 6:549. §-a és a Vht. 236. § (1) bekezdése pedig ezzel összhangban a végrehajtó felelôsségének szabályrendszerét módosította. ${ }^{3}$ A Vht. 240/D. § (1) bekezdése kimondta továbbá, hogy „az önálló bírósági végrehajtó-helyettes bár önállóan foganatosíthat eljárási cselekményeket, de a tevékenységéből esetlegesen eredô kártérítési, illetve sérelemdíj iránti igényeket a végrehajtóval szemben kell érvényesíteni”, valamint a Vht. 241. § (4) bekezdése lényegében a végrehajtójelölt által végzett tevékenységre is kiterjesztette a végrehajtó ilyen irányú felelósségét.

\section{A SÉRELEMdíJ}

A személyiségi jogok megsértése esetén a Ptk. szankcióként nevesíti a sérelemdíjat. A Ptk. szabályozási rendszere összhangban van az Alaptörvény Szabadság és felelôsség fejezetében foglaltakkal. ${ }^{4}$ Az Alkotmánybíróság 8/1990. (IV. 23.) AB határozatában kimondja, hogy „az általános személyiségi jog anyajog, azaz olyan szubszidiárius alapjog, amelyet mind az Alkotmánybíróság, mind a bíróságok minden esetben felhívhatnak az egyén autonómiájának védelmére, ha az adott tényállásra a konkrét, nevesített alapjogok egyike sem alkalmazható". Ugyanakkor a jogellenesség tekintetében kivételként kell kezelni többek között azokat az eseteket, amikor jogszabályi felhatalmazás alapján kerül sor olyan cselekményre, amely sérti más személyiségi jogait. További probléma- 
ként jelentkezhet a késóbbiekben az, hogy a személyiségi jogoknak a Ptk. 2:43. §-ban felsorolt, nevesített listája nem taxatív jellegú, hanem exemplifikatív, azaz további személyiségi jogok alakulhatnak ki. ${ }^{5}$ A sérelemdíj fogalmához kötôdô személyiségi jogok felsorolása tehát nem kizárólagos, mert természetesen nem lehetséges minden, az embert hátrányosan érintố immateriális károsodást nevesíteni. A bírósági végrehajtás oldaláról pedig ezzel párhuzamosan jelentkezik az a kétségtelen tény, hogy minden egyes végrehajtási ügy egyedi a maga vonatkozásában.

A bírósági végrehajtás foganatosítási szakaszában egyértelmú és evidens módon találkozunk pl. a magántitok, a személyes adatok védelme, a magánlakáshoz és a jogi személy céljaira szolgáló helyiségek védelméhez való jog stb. fogalomköre által meghatározható személyiségi jogokkal. A kérdéskörhöz közvetlenül kapcsolódóan ki kell emelni az Alaptörvénynek a tulajdonhoz, a gazdasághoz, az emberi méltósághoz és az információs önrendelkezési joghoz kapcsolódó rendelkezéseit. A törvények szintjén a Ptk., a Vht. és a 2011. évi CXII. (Infotv.) törvény vonatkozó rendelkezései irányadóak. Ténykérdés, hogy a bírósági végrehajtó a részére nyújtott törvényi felhatalmazás alapján gyújt és kezel olyan adatokat, amelyek a személyes adatok körébe tartoznak. Teszi mindezt az adatgyújtés és az adatkezelés célhoz kötöttsége alapelvének betartásával, hiszen az adatgyújtés és adatkezelés számára, mint a bíróság hatáskörében eljáró adatkezelô számára, a vonatkozó kötelezettségeinek teljesítése céljából szükséges eljárási elemek sorozata, valamint egy harmadik személy (végrehajtást kérô) jogos érdekének érvényesítése céljából szükséges. A 20/1990. (X. 4.) AB határozat kimondja, hogy „a magántitok és a személyes adatok védelméhez való jog tartalma, hogy mindenki maga rendelkezik magántitkainak és személyes adatainak feltárásáról és felhasználásáról. A vagyonra vonatkozó adatok az ember magántitkát képezik, és személyes adatának minôsülnek. A magántitok és a személyes adatok védelméhez való jog törvényi korlátozása csak abban az esetben minősíthetô alkotmányosnak, ha megfelel az Alkotmányban a korlátozásokkal szemben támasztott követelményeknek”. A Vht. 225. § (2) bekezdése kimondja, hogy a végrehajtó eljárása - mint polgári nemperes eljárás - a bíróság eljárásával azonos, ${ }^{6}$ vagyis a bírósági végrehajtás a bírósági eljárás része, és mint ilyen, közhatalmi tevékenységnek minôsül. Az alapvetô jogok biztosának jelentései azt állapítják meg, hogy a bírósági végrehajtó az eljárása során - hasonlóan a közhatalom alapján eljáró közigazgatás múködéséhez - közhatalmat gyakorol. ${ }^{7}$

A sérelemdíj megítélése kapcsán feltétlenül kiemelendô az, hogy az igény megalapozottságának megállapításához elegendô mindösszesen a jogsértés tényének megállapítása, és nem szükséges a sértettet ért hátrányok bizonyítása, így a bizonyítási teher a hátrány tekintetében a kötelezettet terheli, azaz megfordul. A sérelemdíj mértékének meghatározása kapcsán nagyon fontos továbbá az a törvényi rendelkezés, amely szerint ,a sérelemdíj mértékét a bíróság az eset körülményeire - különösen a jogsértés súlyára, ismétlődô jellegére, a felróhatóság mértékére, a jogsértésnek a sértettre és környezetére gyakorolt hatására - tekintettel, egy összegben határozza meg [Ptk. 2:52. $\S(3)$ ]". Itt kell és lehet megvizsgálni a kötelezett kimentésének lehetséges elemeit, a sértettet ért hátrány bizonyíthatóságát és annak mértékét, a jogsértés súlyát, a felróhatóságot, az esetleges ismétlődést és annak jellegét, valamint a jogsértés egyéb hatásait, 
illetve a bíróságoknak el kell határolnia az érintett jogesetet az ún. bagatell ügyektől ${ }^{8}$ is, a Ptk. kártérítéseknél alkalmazott szabályrendszerének figyelembevétele mellett. Az elhatárolás és a bírói mérlegelés ${ }^{9}$ további dimenzióját képezi, hogy adott esetben „a felperes köteles bizonyítani, hogy a kereseti tényelőadás szerinti sérelmet okozó magatartás valóban megvalósítja a személyiségi jogsértést, és azt az alperesként megjelölt személy követte el. A személyiségi jog megsértésétôl meg kell különböztetni továbbá az ennek a szintjét el nem érô, szubjektív érzéseken alapuló érdeksérelmeket is". ${ }^{10}$ A bírósági végrehajtással kapcsolatos esetekkel összefüggésben nem lehet figyelmen kívül hagyni, sốt kifejezetten vizsgálni kell a bírósági végrehajtásra vonatkozó speciális és egyedi felelôsségi szabályrendszer zömében kógens jelleggel bíró előírásait, különös tekintettel a kimentési és felróhatósági okokra, ideértve a Ptk. 1:4. § (1), 6:519. §, 6:520. § d), 6:521. §-ban ${ }^{11}$ foglaltakat is. A bírói gyakorlat szerint a személyiségi jogok is csak a rendeltetésszerú joggyakorlás elvének betartása mellett érvényesülhetnek. Azok gyakorlása tehát nem sértheti mások jogait és törvényes érdekeit. ${ }^{12}$

Nagyon leegyszerúsítve, érdekes kérdést vethet fel már az is, hogy a bírósági végrehajtás, amely jogintézmény a szinguláris vagyoni végrehajtás fố útjának tekinthetô, és ebból a tényból adódóan elvileg mondhatjuk, hogy a társadalom létének és berendezkedésének alapját képezô tulajdoni és a tulajdonjogi rendszerének mint a társadalom alapkövének egyik jogintézménye állhat szemben egy, az Alaptörvény által nevesítetten garanciális védelem alá vont személyhez kötődô szubszidiárius alapjoggal. Mi volt előbb, a tyúk vagy a tojás? Maga a végrehajtás nem új keletú intézmény, hanem az egyik legôsibb, magának az emberiség fejlődésének a törzsekbe való rendeződésekor már csírájában megjelenố vagyoni intézménye volt a meglévô birtokmányokra nézve, amely ôsállapotú végrehajtás a közösen megtermelt javak elosztásának kikényszerítésére szolgált. Tágan értelmezve tehát a legelemibb és legminimálisabbnak tekinthetô társadalmi berendezkedés, társadalmi kultúra kialakulása, a tulajdon, a közös tulajdon, a magántulajdon megjelenése óta beszélhetünk valamilyen végrehajtási (szokás) jogról, végtére is a tulajdon a mindenkori társadalmak egyik legelemibb intézménye ${ }^{13}$ a végrehajtás és a tulajdon pedig ebbôl a kontextusból nézve elválaszthatatlan fogalompárt alkot.

\section{A BÍRóSÁGI VÉGREHAJTÁS}

A bírósági végrehajtó számára a Vht. 1. §-ban meghatározottak („A bíróságok és a jogvitát eldöntố más szervek határozatait, továbbá egyes okiratokon alapuló követeléseket bírósági végrehajtás útján, e törvény szerint kell végrehajtani.”) nem lehetőségként, hanem kötelezettségként jelentkeznek. ${ }^{14}$ A Vht. indokolásának értelmében: „A bírósági határozatokban és egyéb okiratokban foglalt követelések érvényesítése, kötelezettségek kikényszerítése bírósági végrehajtás útján történik, melyet - mint polgári nemperes eljárást - a Vht. szabályoz. A bírósági végrehajtás hatékony múködése nemcsak a konkrét ügyekben született bírósági határozatok érvényesíthetôségéhez szükséges, de fontos szerepe van a jogbiztonság, a teljesítési fegyelem erôsítésében, ennélfogva pedig a jogviták kialakulásának megelôzésében is.” Mindez 
azt bizonyítja, hogy a bírósági végrehajtó eljárása, az alkalmazott eljárás foganatosítási elemei a bírósági végrehajtótól a jogalkotó és a bíróság által elvárt magatartások. A bírósági végrehajtási eljárás célja, hogy a kötelezett önkéntes teljesítésének hiányában, a bírósági határozatokban, a törvény által meghatározott egyéb okiratokban foglalt követelések teljesítését kényszercselekményekkel biztosítsa. A bírósági végrehajtás foganatosításának sajátos rendjéhez hozzátartozik az is, hogy amennyiben az adós távolléte miatt a végrehajtható okiratot nem lehet átadni az adósnak, a végrehajtó az adós távollétében kezdi meg eljárását. ${ }^{15} \mathrm{~A}$ bírósági végrehajtó egyik kötelezettségeként az eljárás foganatosítási szakaszában helyszíni eljárási cselekmény lebonyolítása válhat szükségessé a fokozatosság alapelvének betartása eredményeképpen. A végrehajtó helyszíni eljárási cselekményeinek foganatosítása kiemelkedốen nagy fokú konfrontációs kockázati jellemzốvel bír. A helyszíni eljárás realizációja során a végrehajtó jogosult és köteles a Vht. által tételesen meghatározott kényszerintézkedések megtételére. Ugyanakkor a végrehajtó a helyszínen tapasztaltak alapján, saját mérlegelése szerint ítéli meg az alkalmazandó kényszerintézkedések szükségességét. A Vht. a helyszíni eljárás foganatosítása során a végrehajtó számára megfelelô eszközrendszert biztosít feladatainak elvégzéséhez. A végrehajtási helyszíni eljárási cselekmények foganatosításakor az adósnak - vagy a végrehajtási eljárásban közremúködésre kötelezett más természetes személynek vagy szervezet tagjának - a törvény által elôírt kötelezettségei jelentkeznek. A helyszíni eljárás lefolytatásáról a végrehajtó minden esetben jegyzókönyvet készít, és a jegyzôkönyvnek - további törvényi garanciális elemként - kötelezô tartalmi és formai követelményei vannak, amely tartalmi elemek tartalmaznak személyes adatokat is. A jegyzókönyv másolatát a végrehajtónak át kell adnia a jelen lévố feleknek (adós, közeli hozzátartozó, valamint ideértendố a végrehajtást kérố is). Ha az adott konkrét végrehajtási ügyben érdekelt felek távollétében történố helyszíni eljárási cselekmény foganatosításakor a készülố jegyzôkönyv az egyéb helyszínen tartózkodónak nem adható át, abban az esetben fôszabály szerint postai úton kell kézbesíteni azt az átvételre jogosult félnek. ${ }^{16} \mathrm{~A}$ helyszíni eljárás foganatosítását, eredménytelenség esetén a bírósági végrehajtó több idôpontban, különbözố napszakokban újra megkísérli. Nem feltétlen gátja ugyanakkor az eljárás foganatosításának, ha a kötelezetti oldalról nincs jelen érdekelt fél a helyszínen az adott idópontban.

A bírósági végrehajtás által végzett tevékenység és a kár fogalma egyedi viszonylatban van egymással. Amennyiben azt mondjuk, hogy kárnak minôsül minden olyan hátrány, amely valakit valamely károsító esemény folytán személyében vagy vagyonában károsít, továbbá pluszadalék gyanánt hozzátesszük azt, hogy az 1994. évi LIII. törvény 5 . § (2) bekezdése így szól: „az állami kényszer - e törvény keretei között - elsốsorban az adós vagyoni jogait korlátozhatja, kivételesen az adós személyiségi jogait is érintheti”, akkor szembeötlôvé válik az ellentmondás. A végrehajtót érintô felelôsségi, kárfelelôsségi kérdések természetesen jól elhatárolhatóak abban a jogi értelemben, hogy a bírósági végrehajtó a közhatalmi jogkörében okozott kárért fennálló felelósségével kapcsolatban merültek-e fel (jogszabályi felhatalmazás és részletes jogi szabályozás jellemzik), vagy sem. ${ }^{17} \mathrm{Az}$ elhatárolást el kell végezni, mert a sérelemdíj egyrészt 
nem zárja ki a jogsértéssel okozott kár teljes megtérítését, másrészt nem függvénye az egyéb kártérítésnek (Boytha, 2003). Viszont a bírósági végrehajtónak kötelezettsége - nyilvánvalóan a rendelkezésére álló törvényes eszközök felhasználásával - felderíteni az adós végrehajtás alá vonható vagyontárgyait, és ennek keretében joga, sôt ismételten csak kötelezettsége az ezekre vonatkozó információk és adatok beszerzése, valamint a törvény által előírt kötelessége a bírósági végrehajtás foganatosítási eljárási cselekményeinek - a vonatkozó határidók betartása mellett - realizációja. ${ }^{18}$ Többek között a bírósági végrehajtó a „Vht. 43. §-a alapján a végrehajtás során megtekintheti és átvizsgálhatja az adós lakását és egyéb helyiségét, bármely vagyontárgyát, illetve gazdasági tevékenységével kapcsolatos iratait. Az adós lakása és egyéb helyiségei törvényi fogalom meghatározást a gyakorlat tágan értelmezi. A végrehajtási eljárási cselekmény foganatosításához nem szükséges az, hogy az adós tulajdonában álljanak az érintett helyiségek, vagy ezekbe az adós okirati úton be legyen jelentve. A bírósági végrehajtó által kötelezôen realizálandó helyszíni végrehajtási eljárási cselekmény elvégzéséhez elegendô, hogy az adós abban az adott helyiségben, lakásban tartózkodjék, illetve a helyiségben, lakásban irata, az átvizsgálás körébe esố valamilyen vagyontárgya legyen. Mindezen felül a Vht. 44. §-a alapján a végrehajtó szükség esetén az adós lezárt lakását, a tartózkodási helyéül szolgáló vagy egyéb helyiségét, a hozzájuk vezetô bejáratot, továbbá az adós bútorát vagy más ingóságát felnyithatja.” A bíróságok szervezetérôl és igazgatásáról szóló 2011. évi CLXI. törvény 162. §-a értelmében „a bírósági végrehajtó eljárása nemperes eljárás, a hatáskörében tett intézkedése mindenkire kötelezô”. A Vht. 45/A. § (1) bekezdése analóg módon kimondja, hogy „a végrehajtást foganatosító bíróság 500000 Ft-ig terjedô rendbírsággal sújtja az adóst vagy a végrehajtási eljárásban közremúködésre kötelezett személyt, szervezetet, ha a végrehajtásból eredô, jogszabályban foglalt kötelezettségének nem tesz eleget, vagy a végrehajtást végzô hatóság intézkedésének eredményességét akadályozó magatartást tanúsít”. Mindebbôl következốn a végrehajtási eljárás foganatosítása során akár bármely harmadik személy (pl. szomszéd, a lakókörnyezet egyéb tagja, az okirati címen tartózkodó személy stb.) a végrehajtás eredményes lefolytatása céljából közremúködésre kötelezetté válhat. A bírósági végrehajtók, sajátos jellemzôkkel bíró hivataluknál fogva, az állami igazságszolgáltatási rendszer részét képezik, és mint ilyenek, közhatalmi személynek minôsülnek. A jogintézmény által ellátott funkciók oldaláról vizsgálva, a bírósági végrehajtás az államapparátus része. Az Alkotmánybíróság 46/1991. (IX. 10.) AB határozatában kifejtette, hogy „a bírósági határozatok tiszteletben tartása, a jogerôs bírósági döntések teljesítése - akár jogszerú kényszerítés árán is - a jogállamisággal kapcsolatos alkotmányos értékekhez tartozik". ${ }^{19}$

Az igazságügyi miniszter az Országgyúlés előtt a végrehajtási törvény módosításáról szóló expozéjában a következô módon írta le, jellemezte a bírósági végrehajtás, a bírósági végrehajtók helyzetét és megítélését: „a végrehajtó sosem volt népszerú figura Magyarországon, gyaníthatóan persze másutt sem. A létbizonytalanságba került emberek rettegtek tôle, olyannyira, hogy valóságos negatív irodalmi hôssé vált. Ám bármennyire is népszerútlen a végrehajtó, szükség van rá. Mert az alternatíva ennek a funkciónak a reprivatizációja lenne, pénzbehajtás, önbíráskodás. Demokratikus 
jogállam nem létezhet hatékonyan múködô igazságszolgáltatás nélkül. Az igazságszolgáltatási rendszereknek pedig nélkülözhetetlen eleme a végrehajtás, a végrehajtási szervezet. Az igazságszolgáltatás ugyanis csak akkor érheti el a célját, ha a bírósági döntések önkéntes teljesítés hiányában is érvényesülni tudnak" (Kormany.hu, 2015). Amennyiben az eddig megfogalmazottakat összevetjük, nyilvánvalóvá válik, hogy a bírósági végrehajtási eljárás foganatosítási szakasza a bírósági végrehajtó, és az egyes végrehajtási ügyek érintettjei között igen könnyen konfliktusok alakulhatnak ki. De miért is érdekes mindez? Állíthatjuk azt is, hogy amennyiben a bírósági végrehajtó a rá vonatkozó jogszabályok előírásainak megfelelően végzi a tevékenységét, akkor nem történhet semmi baj. A való élet, a gyakorlat sajnálatos módon sok esetben nem ezt igazolja. A sérelemdíj kapcsán a sértettnek elegendô bizonyítania a jogsértés bekövetkeztének tényét. Egy negatív és fiktívnek minôsíthetô példával élve, a sértetti bizonyítás történhet pl. tanúvallomásokkal igazolt módon is, hiszen mint azt az igazságügyi minisztertôl hallhattuk, a végrehajtói hivatás kifejezetten nem minősül népszerúnek. Egy ilyen jellegú negatív példa megvalósulásához a gyakorlatban elegendô mindösszesen egy közös postaláda és egy esôs idôjárás, amely eredményeképpen a végrehajtó által a postaládában zártan elhelyezett értesítés borítékja felnyílik, és az abban található irat rossz esetben más vagy többek számára is hozzáférhetôvé válik, és máris „sérültek” az érintett fél személyiségi jogai. Ilyen esetben jut fokozott szerephez és kerül elôtérbe a bírói mérlegelés, amely egyrészt az eset összes körülményét, másrészt magánjogi büntetés összegszerúségének elbírálási alapját képezi, mindezt meglévố egységes és töretlen bírói gyakorlat hiányában. Egy ilyen peres eljárás kimenetele enyhén szólva is bizonytalan lesz.

A Vht. speciális elốrásokat fogalmaz meg a végrehajtó számára, így pl. az árverési hirdetmény is tartalmaz az adósra vonatkozó személyes adatokat, amely hirdetmény egyébként bárki számára megismerhetô, vagy pl. ingatlankiürítés során a Vht. 183. (6) bekezdése szerinti jegyző́könyv kifüggesztése mérlegelést lehetôvé sem tevố hivatali kötelessége a végrehajtónak. ${ }^{20} \mathrm{~A}$ Vht. szellemiségére, a végrehajtási eljárás alapelveire - mely egyébként többek között korlátozott adósvédelmet jelent -, a Vht. esetenként egyértelmúen megfogalmazott rendelkezéseire tekintettel megállapítható, hogy a végrehajtási eljárásban nem lehet kizárólagos szempontként érvényre juttatni az adósi személyiségi jogok maradéktalan érvényesülésének tiszteletben tartását és biztosítását.

A Vht. garanciális jogorvoslati elemeket is tartalmaz a végrehajtási eljárás foganatosítási szakaszának egészére kiterjedô módon, így pl. az adóson kívül más személyek is elháríthatják a végrehajtó jogszerútlen kényszercselekményeit, mivel a végrehajtó cselekményei ellen nemcsak a felek, hanem más érdekeltek is kifogást terjeszthetnek elô [Vht. 217. § (1) bek.]. A másik oldalról pedig a bírósági végrehajtó számára maga a Vht. biztosítja eljárásának jogi alapjait. A Vht. 47. §-a a végrehajtó számára rendkívül széles felhatalmazást és jogosítványokat biztosít az adós személyére, vagyonára és a végrehajtás körülményeire vonatkozó információk megszerzése vonatkozásában, de a Vht. 47. § (5) bekezdés garanciális adatvédelmi eszközként kimondja, hogy „a végrehajtó a hivatalos eljárása során tudomására jutott adatokat köteles megvédeni 
a jogosulatlan hozzáférés, nyilvánosságra hozás és azok törvényellenes módon vagy ilyen célból történô felhasználása ellen, azokat csak jogszabályban meghatározott esetben tüntetheti fel az intézkedéseirôl szóló iratokban, és hozhatja mások tudomására”. A 2011. évi CXII. törvény 3. § 2. pontja értelmében személyes adat: az érintettel kapcsolatba hozható adat - különösen az érintett neve, azonosító jele, valamint egy vagy több fizikai, fiziológiai, mentális, gazdasági, kulturális vagy szociális azonosságára jellemzó ismeret -, valamint az adatból levonható, az érintettre vonatkozó következtetés. Látható tehát, hogy a végrehajtási eljárásban keletkezett iratok - így különösen a helyszíni jegyzőkönyv, foglalási jegyzókönyv, hirdetmény stb. - az érintett fél vonatkozásában személyes adatokat tartalmaznak. ${ }^{21}$

\section{ÖSSZEFOGLALÁS}

Látható, hogy a bírósági végrehajtás és a sérelemdíj egymáshoz való viszonya, az egyes végrehajtási eljárási cselekmények foganatosításának megítélése potenciális konfliktushelyzeteket generálhatnak, sôt kijelenthetô, hogy mindez a gyakorlatban, a mindennapi élet során nem csak feltételes módban értendô. A konfliktushelyzetet kiegészítve a konzekvens és töretlen bírói gyakorlat hiányával és a sérelemdíjat óhatatlanul terhelô szubjektív elemekkel, úgy vélem, hogy a vonatkozó jogi szabályozás még további módosításra és finomításra szorul majd a jövőben, különösen abban a nem várt esetben, amennyiben az ilyen jellegú peres eljárások száma esetlegesen növekedik.

A sérelemdíj és a bírósági végrehajtás lehetséges konfliktushelyzeteit részletesebben megvizsgálva, kiemelendóek azok a tények, amelyek szerint egyrészrôl a személyiségi jogok megsértése nem lehet azonos az esetleges szubjektív érzéseken alapuló érdeksérelemmel, másrészrôl nem lehet egyenértékú egy bagatellnek minôsíthetô érdeksérelemmel, mert az ilyen, az egyén önös szempontrendszerét tükrözô valós, de csekély mértékúnek minôsülő vagy vélt érdeksérelmet semmiképpen sem lehet az Alaptörvény által védett személyiségi jogok rendszerével garanciális módon védeni. További, szorosan a kérdéskörhöz kapcsolódó faktumot jelent az is, hogy a sérelemdíj megítélésének eseteiben, napjainkban még szinte teljes egészében hiányzik, vagy ellentmondásokat tükröz az ideális esetben következetesnek minősíthetô bírói gyakorlat, ${ }^{22}$ és ennek okán könnyedén lehetségessé válhat az, hogy az egyes egyedi esetek elbírálása szinte kizárólag a bírói mérlegelés függvényében ítéltetik meg, ami még nem jelent feltétlenül önmagában negatívumot, de nagy valószínúséggel nem jelent objektívnek minôsíthetô racionális döntéshozatalt sem. A fentebb megfogalmazottakból következően az bizonyosan kitúnik, hogy a bíróságoknak egy-egy esetben nem lesz könnyú objektív módon megítélni és döntéseikben érdeminek minôsülô indokolással ellátni (Vékás, 2005:199) ${ }^{23}$ már önmagában a kereset tárgyává tett személyiségi jogsértés bagatell vagy szubjektumhoz kötôdô voltát vagy mértékének meglétét sem, illetve mindezen felül az esetlegesen kirovandó sérelemdíj mint magánjogi büntetés egyösszegú pénzben kifejezett értékének megfelelő mértékú meghatározása is nehézségekbe ütközhet. 


\section{Pataki János István: A birrósági végrehajtás és a sérelemdíj}

\section{JEGYZETEK}

1 Ptk. 2:52. § [Sérelemdíj]. „(2) A sérelemdíj fizetésére kötelezés feltételeire - különösen a sérelemdíjra köteles személy meghatározására és a kimentés módjára - a kártérítési felelôsség szabályait kell alkalmazni, azzal, hogy a sérelemdíjra való jogosultsághoz a jogsértés tényén kívül további hátrány bekövetkeztének bizonyítása nem szükséges. (3) A sérelemdíj mértékét a bíróság az eset körülményeire - különösen a jogsértés súlyára, ismétlődổ jellegére, a felróhatóság mértékére, a jogsértésnek a sértettre és környezetére gyakorolt hatására - tekintettel, egy összegben határozza meg."

2 Vö. Vékás, 2013; Molnár, 2013. „A sérelemdíj kettôs funkciót hivatott betölteni: rendeltetése egyidejúleg a reparáció és a represszió is. A reparáció (kompenzáció) célja a sérelem vagyoni eszközökkel történô ellensúlyozása, a sértett életének megkönnyítése másnemú előnyök vagy lehetôségek biztosításával. Alkalmazása feltételezi a jogsértố szubjektív elmarasztalhatóságát, mértéke vétkességarányos. Ezzel szemben a represszió (elégtételadás) egy olyan speciális magánjogi büntetés, amelynek rendeltetése a megelôzố hatás kifejtése. Ezt a hatást közvetlenül a jogsértố személyét illetôen kell kifejtenie, ezért nincs akadálya a jogosult és a jogsértô vagyoni viszonyai figyelembevételének."

3 Ptk. 6:549. § [Felelôsség bírósági, ügyészségi, közjegyzối és végrehajtói jogkörben okozott kárért]. (1) bekezdése szerint a közjegyzôi és a végrehajtói jogkörben okozott kárért való felelôsségre a közigazgatási jogkörben okozott kárért való felelôsség szabályait kell megfelelôen alkalmazni. A kártérítési keresetnek előfeltétele a rendes jogorvoslat kimerítése. 1994. évi LIII. törvény a bírósági végrehajtásról 236. § (1): „A végrehajtó a végrehajtói múködése körében, illetve az eljárása során okozott kárért kártérítésre és személyiségi jogsértésért sérelemdíj megfizetésére a Polgári Törvénykönyv szabályai szerint köteles."

4 Magyarország Alaptörvénye Szabadság és felelôsség VI. cikk: „(1) Mindenkinek joga van ahhoz, hogy magán- és családi életét, otthonát, kapcsolattartását és jó hírnevét tiszteletben tartsák. (2) Mindenkinek joga van személyes adatai védelméhez, valamint a közérdekú adatok megismeréséhez és terjesztéséhez. (3) A személyes adatok védelméhez és a közérdekú adatok megismeréséhez való jog érvényesülését sarkalatos törvénnyel létrehozott, független hatóság ellenôrzi."

5 Vö. Fuglinszky, 2015:841-845.

6 Vö. FIT-H-PJ-2013-197. bírósági határozat, 10-H-PJ-2008-30. bírósági határozat.

7 56/1991. (XI. 8.) AB határozat: A jogállamiság egyik alapvetô követelménye, hogy a közhatalommal rendelkezô szervek csak a jog által meghatározott keretek között fejthetik ki a tevékenységüket. Vö. 11/1992. (III. 5.) AB határozat; 49/1998. (XI. 27.) AB határozat; 1998, 5/1999. (III. 31.) AB határozat; 422/B/1999. AB határozat; 1993. évi LIX. törvény az állampolgári jogok országgyúlési biztosáról; 2011. évi CXI. törvény az alapvetố jogok biztosáról 18. § k).

8 A Fôvárosi Ítélôtábla Polgári Kollégiuma 1/2013. (VI. 17.) számú határozatával elfogadott kollégiumi véleménye a nem vagyoni kártérítés/sérelemdíj megtérítése iránti követelések elbírálásának a polgári perben felmerülố egyes kérdéseiről. „Különös jelentôsége van annak, hogy a sérelemdíj követelése iránt indult perekben a bíróságok megkülönböztessék a személyiségi jog megsértésétôl az ennek a szintjét el nem érô, szubjektív érzéseken alapuló érdeksérelmeket. Ugyanis a személyiségi jogot nem sértố érdeksérelem nem járhat a sérelemdíj mint jogvédelmi eszköz alkalmazásával."

9 Vö. BH2016. 241. A személyiségi jogi jogsértés megállapításának nem automatikus következménye a sérelemdíj megítélése. A körülmények bírói mérlegelése adott esetben azt is eredményezheti, hogy a jogsértố nem kötelezhetố sérelemdíj megfizetésére.

10 A Fốvárosi Ítélôtábla Polgári Kollégiuma 1/2013. (VI. 17.) számú határozatával elfogadott kollégiumi véleménye a nem vagyoni kártérítés/sérelemdíj megtérítése iránti követelések elbírálásának a polgári perben felmerülố egyes kérdéseirôl. 2.

11 2013. évi V. törvény a Polgári Törvénykönyvrôl. „1:4. § [Az elvárható magatartás elve. Felróhatóság] (1) Ha e törvény eltérố követelményt nem támaszt, a polgári jogi viszonyokban úgy kell eljárni, ahogy az az adott helyzetben általában elvárható. [...] 6:519. § [A felelôsség általános szabálya] Aki másnak jogellenesen kárt okoz, köteles azt megtéríteni. Mentesül a felelôsség alól a károkozó, ha bizonyítja, hogy magatartása nem volt felróható. 6:520. § [Jogellenesség] Minden károkozás jogellenes, kivéve, ha a károkozó a kárt [...] d) jogszabály által megengedett magatartással okozta, és a magatartás más személy jogilag 


\section{Polgári Szemle · 13. évfolyam 4-6. szám}

védett érdekét nem sérti, vagy a jogszabály a károkozót kártalanításra kötelezi. 6:521. § [Elôreláthatóság] Nem állapítható meg az okozati összefüggés azzal a kárral kapcsolatban, amelyet a károkozó nem látott elốre és nem is kellett elôre látnia."

12 Vö. BH1992. 387.

13 Vö. Harmathy, 1989; 217-228., passim; Téglási, 2008, 67-133., passim; Kovács, 1989.

14 Vö. Fôvárosi Ítélótábla 9. Pf. 20.627/2011/7.

15 A törvényhely alkotmányossági felülvizsgálata során az Alkotmánybíróság a 994/B/1997. AB határozatában megállapította, hogy „a kézbesítés és a foganatosítás megkezdésének egybeesését lehetôvé tévố szabályt önmagában nem lehet értékelni, azt a Vht. egyéb rendelkezéseivel összefüggésben kell megítélni”.

16 250/2004. (VIII. 27.) Korm. rendelet a végrehajtói kézbesítés részletes eljárási szabályairól. „Értesítés a kézbesítés megkísérlésérôl. 26. § (1) Ha a címzett a bírósági határozatban a címeként feltüntetett címen megtalálható, de a végrehajtó a helyszíni eljárása alkalmával nem találja ott sem ôt, sem a helyettes átvevôt, a címzett levélszekrényében értesítést hagy a címzettnek arról, hogy kézbesítés céljából a címen megjelent, és a bírósági iratot a címzett hol, milyen idôszakban és milyen okiratok bemutatása ellenében veheti át (a továbbiakban: értesítés). (2) Ha a címzettnek nincs zárható vagy beazonosítható levélszekrénye, a végrehajtó az ingatlan bejáratára (ha az erre nem alkalmas, falára) tűzve hagy értesítést a címzettnek. Így járhat el a végrehajtó akkor is, ha egyidejúleg a levélszekrényben is hagy a címzett részére értesítést."

17 994/B/1997. AB határozat a Vht. 36. §, valamint a 43., 44., 45. §, továbbá 58. §, 217. §, 221. § b) és 222. § alkotmányellenességének vizsgálatáról hozott döntésében az $\mathrm{AB}$ valamennyi indítványt elutasította. Kimondta, hogy „az Alkotmánybíróság következetes gyakorlata szerint az alapvetô jog korlátozása csak akkor marad meg az alkotmányos határok között, ha a korlátozás elkerülhetetlen, azaz más alkotmányos alapjog, valamint alkotmányos érték védelme vagy érvényesülése, illetve az Alkotmányból következô feladat megvalósítása más módon nem biztosítható, továbbá, ha az elérni kívánt cél fontossága és az ennek érdekében okozott alapjogsérelem súlya arányban áll egymással. E körbe tartozik a végrehajtás során kialakuló jogkorlátozás is".

18 Vö. Kúria Pfv.VIII.22.160/2011/4; Legfelsốbb Bíróság Pfv.V.20.363/2009/6; Fơvárosi Ítélôtábla 9.Pf.20.462/2011/5; Fôvárosi Ítélôtábla 9. Pf. 20.627/2011/7; Fôvárosi Ítélôtábla 9.Pf.20.458/2010/3; Pécsi Ítélootábla Pf.III.20.185/2011/9; Heves Megyei Bíróság P.20.243/2005/36; Pest Megyei Bíróság 14.P.29.066/2008/2.

19 Vö. Az alapvetố jogok biztosának jelentése az AJB-209/2013. számú ügyben (Kapcsolódó ügyek: AJB2460/2013., AJB-6123/2012., AJB-4567/2012.).

20 250/2004. (VIII. 27.) Korm. rendelet a végrehajtói kézbesítés részletes eljárási szabályairól. „Értesítés a kézbesítés megkísérlésérôl. [...] 26. § (2) Ha a címzettnek nincs zárható vagy beazonosítható levélszekrénye, a végrehajtó az ingatlan bejáratára (ha az erre nem alkalmas, falára) tûzve hagy értesítést a címzettnek. Így járhat el a végrehajtó akkor is, ha egyidejúleg a levélszekrényben is hagy a címzett részére értesítést. 27. § (1) Értesítést kell a címzett részére hagyni akkor is, ha a végrehajtó a címzetten, illetve helyettes átvevôn kívül más személyt talál a kézbesítési helyen. Ilyenkor az értesítés egy példányát lehetôség szerint ennek a személynek is át kell adni. (2) Értesítést kell a címzettnek hagyni akkor is, ha a bírósági irat átvételét megtagadta."

21 373/D/2005. AB határozat: „A Vht. 47. § (1) bekezdése »szükség esetén« szövegrésze, 52. § d), f) pontja, 54. § (1) bekezdésének d), f) pontja, valamint (2) bekezdése alkotmányellenességének megállapítására vonatkozó indítványokat az AB elutasította. A végrehajtó e tényállásokban biztosított jogköre nem sérti sem a tulajdonhoz való jogot, sem más alkotmányos jogot. A végrehajtó adatbeszerzése az eredményes végrehajtás feltétele, a többi támadott intézménnyel együtt meghatározzák a végrehajtó mozgásterét, biztosítják számára azt a lehetôséget, hogy a konkrét ügyhöz viszonyítva határozza meg a végrehajtás eszközeit."

22 Vö. Lábady, 2016. „Az alig több mint másfél éve hatályos törvényi rendelkezések alapján az elsôfokú bíróságok kétféle - egymással ellentétes - álláspontot alakítottak ki: a) Az egyik szerint a Ptk. rendelkezései nem adnak mérlegelési lehetôséget abban a kérdésben, hogy a személyiségi jog megsértésének jogkövetkezményeként a bíróság ítél-e meg sérelemdíjat, csak a sérelemdíj összegének meghatározása lehet 


\section{Pataki János Istuán: A birósági végrehajtás és a sérelemdíj}

bírói mérlegelés tárgya. b) A másik álláspont szerint a személyiségi jogsértés megállapítása, valamint az objektív szankciók megítélése mellett is a bíróság elutasíthatja a sérelemdíj iránti keresetet, ha álláspontja szerint a sérelmet szenvedett felet nem érte olyan immateriális sérelem, amely sérelemdíj megítélésére adhatna alapot."

23 „A bírónak tisztában kell lennie azzal, hogy az adott esetben mely okból és milyen céllal ítél meg sérelemdíjat, és az ítéleti indoklásából világosan ki kell túnnie a fájdalomdíjként megítélt összeg megállapításánál figyelembe vett kompenzációs, illetve elégtételadási szempontoknak.”

\section{FELHASZNÁLT IRODALOM}

Boytha György (2003): A személyiségi jogok megsértésének vagyoni szankcionálása. Polgári Jogi Kodifikáció, 5. évf., 1. sz., 3-6. o.

Fuglinszky Ádám (2015): Kártérítési jog. HVG-ORAC, Budapest.

Harmathy Attila (1989): A tulajdonjog alkotmányos védelme. Jogtudományi Közlöny, 44. évf., 5. sz., $217-228$.

Kormany.hu (2015): Trócsányi László a bírósági végrehajtásról szóló törvény módosításáról. Kormany.hu, június 12.

Kovács István (1989): Magyar államjog II. JATE Kiadó, Szeged.

Lábady Tamás (2016): Sérelemdíj versus nem vagyoni kártérítés. Állam-és Jogtudomány, 57. évf., 1. sz., 40-45. Molnár Ambrus (2013): A sérelemdíj elméleti és gyakorlati kérdései. Kúriai Döntések, 61. évf., 7. sz., $744-748$.

Osztovits András (szerk.) (2014): A Polgári Törvénykönyvrôl szóló 2013. évi V. törvény és a kapcsolódó jogszabályok nagykommentárja I. Opten Informatikai Kft., Budapest.

Téglási András (2008): A tulajdonhoz való jog alkotmányos védelme - Történeti áttekintés. De Iurisprudentia et Iure Publico, 2. évf., 4. sz., 67-133.

Vékás Lajos (2005): Sérelemdíj - fájdalomdíj: Gondolatok az új Ptk. reformjavaslatáról a német jog újabb fejleményei tükrében. Magyar Jog, 52. évf., 4. sz., 193-207.

Vékás Lajos (2013): Az új Polgári törvénykönyvrôl. Jogtudományi Közlöny, 68. évf., 5. sz., 225-242. 